\title{
Evaluation of Er:YAG lasers on pain perception in pediatric patients during caries removal: a split-mouth study
}

\author{
Emre Korkut, ${ }^{*}$ Onur Gezgin, Hazal Özer, \\ Yağmur Şener \\ Department of Pediatric Dentistry, Faculty of Dentistry, \\ Necmettin Erbakan University, Konya, Turkey
}

\begin{abstract}
OвJECTIVE: Fear and anxiety is a major problem in the treatment of pediatric patients. The pain that occurs during the use of caries removal instruments has a strong potential of triggering dental anxiety and fear in most children and adults. This study aimed to evaluate and compare the pain perceptions of children who underwent caries removal via an Er:YAG laser and traditional rotary instruments.
\end{abstract}

Materials and Method: Occlusal caries was removed from the permanent molar teeth of $\mathbf{1 2 0}$ pediatric patients who referred to the Department of Pediatric Dentistry, Faculty of Dentistry, Necmettin Erbakan University, using an Er:YAG laser and high- and low-speed rotary instruments. All restorative procedures were performed by one clinician. The participant children were asked to choose a value or figure from the Wong-Baker FACES Pain Rating Scale, and the data were analyzed using the Wilcoxon test $(\alpha=0.05)$.

RESULTS: A statistically significant difference was found between the groups $(p<0.05)$. In the Er:YAG laser group $20.83 \%$ of the participants, and in the conventional group, $6.66 \%$ of the participants selected the option 'no hurt'. The option 'hurts worst' was selected in neither of the groups.

Conclusion: The use of Er:YAG laser for caries removal causes less or no pain during the operations, compared to traditional rotary instruments. Therefore, it can be argued that Er:YAG laser is a more comfortable and acceptable alternative for pediatric patients.

KEYwORDS: Dental caries; Er-YAG lasers; pain perception; pedodontics

Citatıon: Korkut E, Gezgin O, Özer H, Şener Y. Evaluation of Er:YAG lasers on pain perception in pediatric patients during caries removal: a split-mouth study. Acta Odontol Turc

Received: March 06, 2017; Accepted: October 12, 2017

${ }^{*}$ Corresponding author: Dr. Emre Korkut, Karaciğan Mah., Ankara Cad.,

No: 74/A, 420250, Karatay, Konya, Turkey;

E-mail: ekorkut@konya.edu.tr
2018;35(3):81-6

EdIToR: Neşe Akal, Gazi University, Ankara, Turkey

Copyright: () 2018 Korkut et al. This work is licensed under a Creative Commons Attribution License. Unrestricted use, distribution and reproduction in any medium is permitted provided the original author and source are credited.

FundiNG: None declared.

CONFLICT OF INTEREST: The authors declare no conflict of interest related to this study.

\section{INTRODUCTION}

Fear from and anxiety about the dentists and dental treatment are two of the most important reasons that people avoid dental treatment. ${ }^{1}$ The worry that individuals feel during protective operations or in a need for dental treatment is called dental anxiety. It is a common situation that usually emerges in childhood or adolescence..$^{1,2}$

Fear and anxiety is a major problem in the treatment of pediatric patients. Children may be affected negatively by a number of factors including dental instruments and equipment, treatment methods, pain caused by the treatment, learned-helplessness created by anxious family members, and the presence of strangers and adults that work at the dental clinic. Some studies have also shown that anxiety and fear related to dental treatment may affect daily life, and family and social interactions ${ }^{1-4}$ Anxiety may also be triggered by sensory triggers including the air pressure created by rotary instruments, sight of the needle, and the smell of eugenol and dentin after being cut. The most common fear that triggers dental anxiety is the fear of pain. ${ }^{1}$ The correlation between fear and pain is highly important for dentists. Even though the concept of pain is usually evaluated within a physiological process, it also has a strong psychological component, which leads to a possibility that people with dental anxiety may have exaggerated pain expectations and pain perceptions. Clinicians are supposed to know that relieving pain in patients does not relieve their fear and anxiety as well. If patients' anxiety and treatment are not managed in 
a suitable and synchronized manner, it is possible that they may fall into a 'vicious circle of dental fear'. Some patients avoid visiting their dentists due to fear, which worsens their problems, thereby requiring more intensive and traumatic treatments in time. This strengthens their fear or makes it more severe. Thus, the process of avoiding dental treatment continues. ${ }^{3}$ In addition, negative experiences in childhood may cause a lifetime dental phobia. Therefore, the psychological evaluation of children before treatment is vital in the early diagnosis of dental anxiety.

A number of caries treatment methods have been developed in recent years, which cause less anxiety in children than the conventional methods. The use of conventional caries removal instruments (e.g. diamond and tungsten carbide rotary instruments) has a strong potential of triggering dental anxiety and fear in most children and adults. Although the pain may be relieved by local anesthesia, other reasons exist for anxiety and fear including the fear of the needle, the noise of mechanical operations, and the fear of vibration. Moreover, the high- and low-speed rotary instruments used to remove deep dentinal caries may damage the dentin and pulp during the operation. These disadvantages have led to the search for alternative methods that are more advantageous than the methods removing the caries completely, as well as those that enable performing the treatment in stages or partially, or do not reach the dentin. ${ }^{5}$ It has been claimed that the new methods in restorative dentistry may eliminate a number of painful or discomforting aspects of dental operations, and reduce the fear and anxiety of pain during the treatment. It should also be considered that high-speed rotary instruments have been listed for a long time among elements that cause the strongest anxiety in dentistry. A study conducted by Oosterink et al. ${ }^{4}$ determined that the item "the dentist's operating on your teeth with rotary instruments" was the $20^{\text {th }}$ in a list of 67 potential warnings.

In 1997, the United States Food and Drug Administration gave approval after extensive studies for the use of erbium-doped yttrium aluminum garnet (Er:YAG) laser in caries removal operations. ${ }^{6}$ It is commonly acknowledged that the Er:YAG laser with a wavelength of $2940 \mathrm{~nm}$ is the one that has the best absorption in water. The energy absorption created by the photoablation mechanism enables the safe use of Er:YAG laser in hard tissues. Energy discharge is only realized by absorption in superficial layers of hard tissues (e.g. bone, cement, enamel, and dentin). Therefore, there is no thermal damage in deeper tissues.

Laser is an alternative treatment method for those who suffer from discomfort caused by the noise and vibration of the traditional rotary instruments or worried about having pain. Moreover, it reduces the need for anesthesia, which is a reason for fear and anxiety in most children and adults with anxiety. Even though it is assumed that lasers reduce anxiety thanks to their utilization aspects, few studies have tested this assump- tion. A study conducted in Switzerland in 2014 found that laser caused less pain and anxiety compared to local anesthesia and rotary instruments. ${ }^{7}$ That study also reported that the most favorable characteristics of the laser were that it was painless and fast, was not related to any noise or vibration, and did not require local anesthesia, which were usually regarded as sources of anxiety related to rotary instruments.

The aim of this study was to evaluate and compare the pain perceptions of children who underwent caries removal in their permanent molar teeth using Er:YAG laser and traditional rotary instruments. The null hypothesis was that there would be no statistically significant difference between Er:YAG laser and conventional caries removal methods on the pain perception of pediatric patients.

\section{Materials ANd Method}

The present study was conducted under the approval of the Ethics Committee of Necmettin Erbakan University, Faculty of Dentistry (Protocol number 2017-02). The study population consisted of 120 children (65 male / 55 female; 240 teeth) between 8 and 12 years of age who referred Necmettin Erbakan University Pediatric Dentistry Clinic in Konya, Turkey.

The sample size was estimated using the GPower analysis (Ver.3.0.10 Franz Paul, Christian-AlbrechtsUniversity, Kiel, Germany). It was found that a total sample size of 190 teeth would give $90 \%$ power to detect significant differences. However, to avoid data loss, the sample size was determined as 240 teeth.

A total of 240 carious teeth were treated by Er:YAG laser $(n=120)$ and conventional methods $(n=120)$. The teeth were randomized using the R 2.11.1 (R Foundation for Statistical Computing, Vienna, Austria) software. At the first treatment session, the conventional method was applied on the first carious molar of all participants. The Er:YAG laser method was performed at the following treatment session. The inclusion criteria were:

-No systemic disease,

-First dental visit,

-Contra-lateral presence of occlusal dentinal caries on first permanent molars (score 3 according to the International Caries Detection and Assessment System II (ICDAS II) classification),

-Speaking Turkish as the native language,

-Behavioral rating of Frankl's 3 or Frankl's 4,

Informed consent was obtained from all participant parents. The benefits and possible side effects such as popping sounds and malodor were fully explained. Cavities were prepared using the split-mouth study design. Cavity preparations were performed by the same pediatric dentist to ensure that the results were not influenced by inter-operator variability. No local anesthetic was administered. 
Table 1. The proportions of self-reported values of pain perception after the Er:YAG laser and conventional method applications

\begin{tabular}{ccccc}
\hline Pain perception value & \multicolumn{2}{c}{ Conventional method } & \multicolumn{2}{c}{ Er:YAG laser } \\
\hline $\mathbf{0}$ & $\mathbf{n}$ & $\%$ & $\mathbf{n}$ & $\%$ \\
$\mathbf{2}$ & 8 & 6.66 & 25 & 20.83 \\
$\mathbf{4}$ & 26 & 21.66 & 41 & 34.16 \\
$\mathbf{6}$ & 50 & 41.66 & 40 & 33.33 \\
$\mathbf{8}$ & 22 & 18.33 & 14 & 11.66 \\
$\mathbf{1 0}$ & 14 & 11.66 & 0 & 0 \\
Total & 0 & 0 & 0 & 0 \\
\hline
\end{tabular}

The manufacturer's instructions were followed for cavity preparation in the Er:YAG laser group using the Er:YAG laser (Lightwalker, Fotona Technology, Ljubljana, Slovenia) 2,940 nm wavelength parameters. In addition, the researchers followed the guidelines for laser treatment, including the use of protective eyewear, for the safe use of the laser. Laser settings were adjusted as $300 \mathrm{~mJ}, 20 \mathrm{~Hz}$ and $9 \mathrm{~W}$ for enamel preparation. The cavity was prepared through back-forth and up-down moves to remove caries. For dentine preparation, pulses were applied at a repetition rate of $4 \mathrm{~Hz}$ and power of $3 \mathrm{~W}$, with a pulse energy of $250 \mathrm{~mJ}$. During laser interaction, dentinal surfaces were moistened by continuous water irrigation $\left(1.5 \mathrm{~mL} / \mathrm{min}^{-1}\right)$.

Traditional cavity preparation method used the highspeed and low-speed hand-pieces. Preparations were performed under water and air-cooler, being visually controlled through intermittent testing of the hardness of the remaining hard tissue using a dental probe.

All cavities were restored using the same bonding agent (Nova Compo-B Plus Adhesive, Imicryl, Konya, Turkey) and light-cure resin (Filtek ${ }^{\mathrm{TM}}$ Supreme Ultra Universal Restorative, 3M, Minneapolis, MN, USA).

Immediately after the treatment, each child was asked to point the degree of his/her pain on the WongBaker FACES Pain Rating Scale ${ }^{8}$ (Figure 1), a selfreport instrument that includes six icons ranging from 'No Hurt' to 'Hurts Worst' in combination with a series of consecutive numbers (0-2-4-6-8-10). The children pointed the face or select the number which most describes their pain during the treatment.

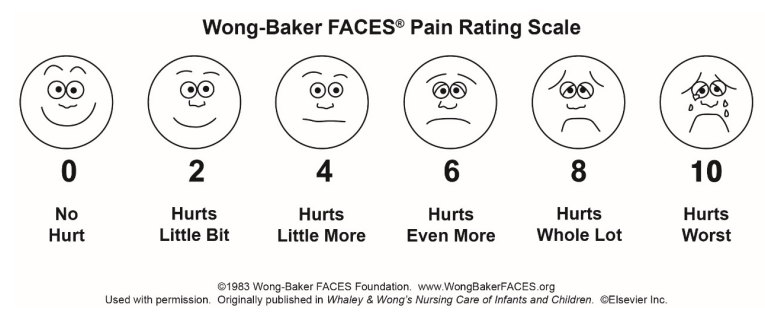

Figure 1. Wong-Baker FACES ${ }^{\circledast}$ pain rating scale ${ }^{8}$
The data were statistically analyzed using the Wilcoxon test to test for the differences between groups $(\alpha=0.05)$. Data analysis was performed using the SPSS 22.0 (Statistical Package for the Social Sciences, SPSS Inc, Chicago, IL, USA), and $\mathrm{p}<0.05$ was accepted to be statistically significant.

\section{Results}

Of the children, $20.83 \%$ in the Er:YAG laser group and $6.66 \%$ in the conventional method group selected the icon 'no hurt'. The option 'hurts little bit' was selected by $34.16 \%$ and $21.66 \%$ of the children in the Er:YAG laser and conventional treatment groups, respectively. For the Er:YAG laser treatment, $33.33 \%$ of the children, and for the conventional treatment, $41.66 \%$ of the children selected the option 'Hurts Little More'. Of them, $18.33 \%$ in the conventional method group and $11.66 \%$ in the Er:YAG laser group selected the option 'hurts even more'. Only $14(11.66 \%)$ children in the conventional method group selected the option 'hurts whole lot'; and none of the children in the Er:YAG laser group selected the option 'hurts whole lot'. Neither of the groups selected the option 'hurts worst' (Table 1 and Figure 2).

The children in the Er:YAG laser group selected significantly lower values on the scale compared to those in the conventional method group (Table 2; $p<0.05$ ).

\section{Discussion}

Every child experiences anxiety at different levels. Thus, their tolerance for anxiety varies as well. Anxiety and pain are also strongly correlated. Dental anxiety is

Table 2. Pain perception values of conventional and Er:YAG laser applications

\begin{tabular}{lccccc}
\hline & $\mathbf{n}$ & Mean & $\begin{array}{c}\text { Standard } \\
\text { error }\end{array}$ & $\begin{array}{c}\text { Wilcoxon } \\
\mathbf{z}\end{array}$ & Significance \\
\hline Conventional & 120 & 4.1333 & 0.19480 & & \\
Er:YAG Laser & 120 & 2.7167 & 0.17198 & & $\mathrm{p}<0.00$ \\
\hline
\end{tabular}




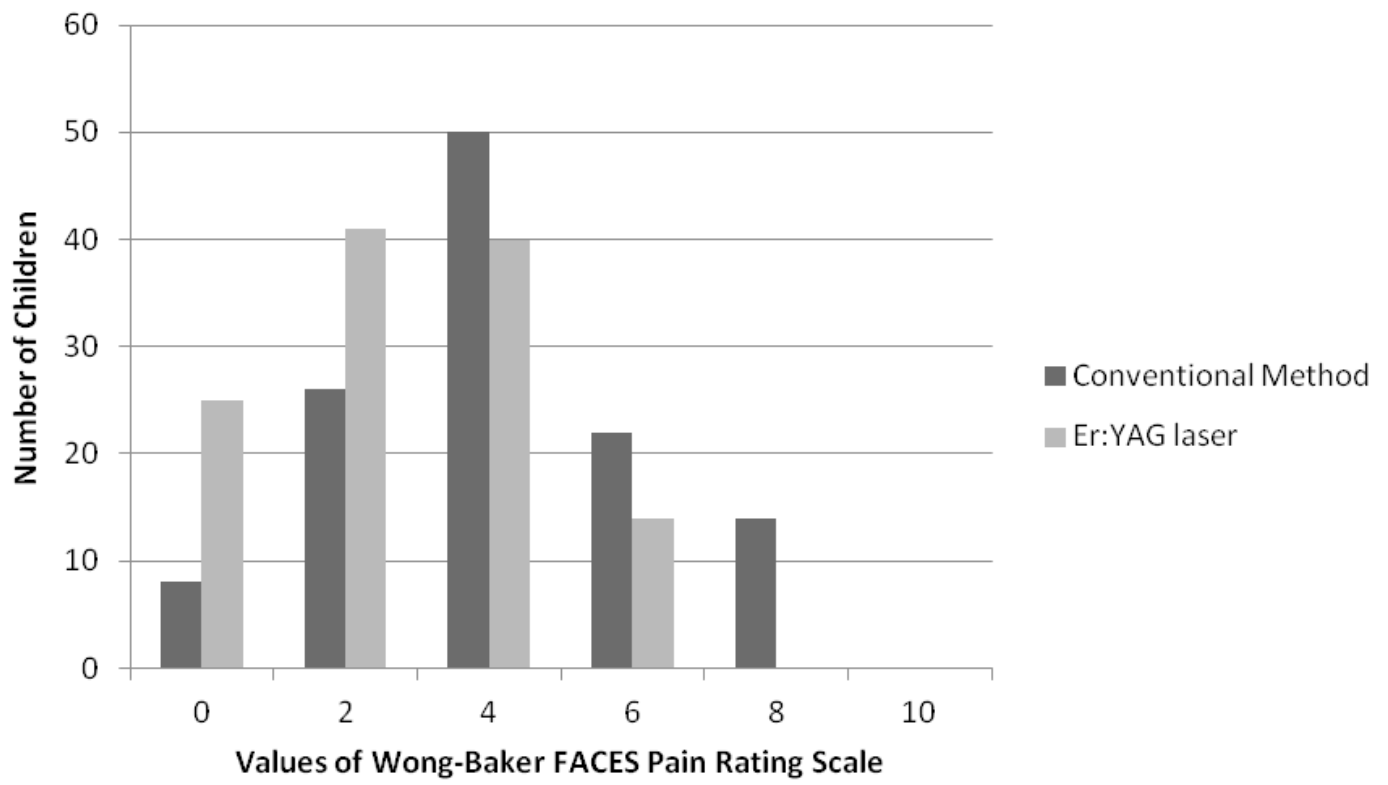

Figure 2. The values of self-reported pain perception after the Er:YAG laser and conventional method applications

different from general anxiety. It is a reaction that may result from poor dental session experiences in the past. Certain operations (e.g. operating on a deep cavity without anesthesia) act as unconditional stimuli, and the individual develops an unconditional response against these stimuli. When different stimuli are added to the painful treatment (e.g. the smell in the environment, the vibration of the instruments), pediatric patients develop conditioned reflexes. Children with dental anxiety believe that they will suffer from more pain than normal, and are psychologically uncomfortable on visiting the dentist. Consequently, they insist not to have their dental treatment. ${ }^{9}$ Pediatric dentists prefer the techniques and strategies that help to improve the behaviors of pediatric patients. The success of the treatment administered to pediatric patients depends not only on the quality of the treatment, but also on inflicting a positive attitude to children about dental care and regular visits to the dentist.

The determination of dental anxiety in children using scales is important for early diagnosis and evaluation of the needs. To date, researchers have used behavioral scoring, psychometric assessments, psychological tests, and projective techniques to determine dental fear and anxiety. Psychometric methods demonstrate patients' fear and anxiety through direct questions. Physiological techniques make use of physiological assessment methods. These assessments measure dental fear in an indirect manner (e.g. heart rate, pulse rate, response of the dorsal skin). Projective techniques enable the researcher to have an opinion about the hidden feelings in the subconscious. They also require children to make comments on some pictures. Researchers make an effort to reveal the relation between the children's feelings and the picture they imagine. $^{2}$

Behavioral scoring is not authorized to determine fear and anxiety since it is not based on an objective evaluation. Likewise, psychometric assessments identify the situation expressed by the children, and they are based on the subjective evaluation of the physician. These assessments are accepted to be subjective and lasting longer than the children's attention span. On the other hand, psychometric assessment methods are based on blood pressure, pulse, and dorsal skin response data, all of which require the use of equipment. In projective techniques, children can empathize and express themselves in the best way. Children are asked to select the option that they feel the closest to, and they will select an option before losing their concentration.

Researchers have created multiple-choice scales to evaluate pain in children. The most popular tests administered to pediatric patients include Corah's Dental Anxiety Scale, Children's Fear Survey Schedule-Dental Subscale, Children's Dental Fear Picture Test-Dental Setting, Children's Dental Fear Picture Test-Pointing Pictures, Children's Dental Fear Picture Test-Sentence Completion, Venham's Picture Test, Facial Images Scale, Kleinknect's Dental Fear Scale, and Frankl Behavior Scale. The pain evaluation scales are usually based on area sampling or psychosocial scaling. Area sampling provides the qualitative and categorical assessments of the pain, and psychological scaling provides the quantitative and continuous data. ${ }^{10}$ However, none of these tests have been accepted as gold standards due to their limitations. ${ }^{2}$ Facial expression drawings are frequently used when working with pediatric patients. 
Venham's Anxiety Scale (VAS) is the most popular pain evaluation scale in acute pain studies. VAS is a type of cross-modal matching that is set to match the length of one line to the intensity of the pain perception, and has been analyzed many times as a tool for pain evaluation. Bijur et al. ${ }^{11}$ observed that VAS is a reliable tool for assessing acute pain in adults. It enables researchers to evaluate the discomfort at the beginning, and the response to the treatment as well. The ability of VAS to convert the feeling of pain into an assessable unit may be affected by a number of patient characteristics including age, ability to speak fluently, visual acuity, motor functions, and cognitive ability. Also, children may not have sufficient perception to make the 'real' pain description abstract. ${ }^{12}$

There are a few studies that correlate VAS with the alternative methods to evaluate the severity of pain. Bulloch \& Tenenbein ${ }^{13}$ conducted a study with 60 children, reporting that there was a flawless correlation between FACES Pain Scale and Color Analog Scale, a form of VAS. Both of these methods were reliable, created with the aim of assessing acute pain in children aged between 5 and 16 years. In contrast, Bailey \& Trottier $^{14}$ found no consistency between the VAS and Wong-Baker FACES Pain Rating Scale in their evaluation of pediatric patients in the emergency service.

Researchers need to consider the developmental statuses of children to have them answer all of the questions in the scale themselves during the assessment. ${ }^{2}$ There are many studies that have proved the difficulty of assessing pain in children younger than seven years using VAS. ${ }^{2,12}$ This finding is consistent with Piaget's cognitive development stages. In general, children enter into the concrete operational stage as of 7 to 11 years of age. In this stage, they are able to follow serial directions. These operations are related to the generalization ability of children and based on the reasoning of relations. ${ }^{15}$ Shields et al. ${ }^{16}$ demonstrated that only one-thirds of the children aged between 5 and 14 years comprehended the concept of VAS related to pain management. They also stated that the patients who were able to understand the VAS concept were older than those who could not (aged between 11 and 14 years and between 5 and 10 years, respectively). The present study employed Wong-Baker FACES Pain Rating Scale for children aged between 8 and 14 years due to its effectiveness in this group.

In the past, researchers have made efforts to develop local anesthesia and caries removal methods with the aim of reducing dental pain and the resulting anxiety. The methods that have been developed so far are abrasive, kinetic, sonic, chemo-mechanic, enzymatic, and laser caries removal methods. There are many studies in the relevant literature examining the effects of caries removal methods on anxiety. However, few studies have compared the levels of anxiety that these methods caused in patients.

Chomyszyn Gajewska et al. ${ }^{17}$ made a comparison between the Vector system (Duerr Dental, BietigheimBissingen, Germany) and the conventional caries removal method considering pain perception and the period of time needed. That study was conducted on 30 children and found that the Vector system had a minimum effect on pain perception, while it required a significantly longer administration time.

Topaloğlu et al. ${ }^{18}$ investigated the effects of chemomechanical and conventional caries removal methods on the dental anxiety among children and found no statistically significant difference between these methods.

A study conducted in India with 30 children and 60 teeth compared the chemo-mechanical caries removal method with the conventional methods, considering the behavioral scoring scale, pain perception, and treatment preferences. It was observed that children who underwent caries removal by the chemo-mechanical method were more comfortable than the other group. Yet, there was no statistically significant difference between preand post-treatment behaviors of the two groups. ${ }^{19}$

Kumar et al. ${ }^{20}$ examined 80 baby molar teeth using the atraumatic restorative technique as well as chemomechanical caries removal methods, and reported that the chemo-mechanical method took a longer time, but it was more acceptable to pediatric patients.

The present study employed the Er:YAG laser method because of safe photo-ablation of the hard tissue, and the best absorption in water compared to the other types of laser.

Dommisch et al. ${ }^{21}$ compared the Er:YAG laser and the rotary instruments on adult patients. They found that more than $75 \%$ of the patients reported no pain during the Er:YAG laser treatment, and $20 \%$ of the patients treated by the conventional method felt no pain during the caries removal. Ninety percent of the patients described the Er:YAG laser application as comfortable thanks to perceived vibration. None of the patients in the Er:YAG laser group reported the operation as uncomfortable, while $38 \%$ of the patients in the conventional method group stated that the operation was uncomfortable.

In the present study, the pain perceptions of the pediatric patients were determined using Wong-Baker FACES Pain Rating Scale in accordance with the literature. The results showed that caries removal with Er:YAG laser had statistically significant positive effects on pain perception compared to the conventional method, which led to the rejection of the null hypothesis of this study. These results may be related to the undesirable vibration effect of the rotary instruments.

The results of the present study are also consistent with the results found by Eren et al. ${ }^{22}$ who compared Er:YAG laser with mechanical caries removal method, and by Hjertton \& Bagesund ${ }^{23}$ who compared Er:YAG laser with conventional methods. Both of these studies demonstrated that laser administration on soft and hard tissues caused less pain than the conventional 
methods, or caused no pain at all. Some of the children wished to continue their treatment with the Er:YAG laser because the laser did not cause any sense of pressure, heat or pain.

\section{ConcLusion}

Based on the results of the present study, it was concluded that the use of Er:YAG lasers causes less or no pain during caries removal, and is a more comfortable and acceptable alternative for pediatric patients compared to the traditional rotary instruments.

\section{References}

1. Appukuttan DP. Strategies to manage patients with dental anxiety and dental phobia: literature review. Clin Cosmet Investig Dent 2016;8:35-50.

2. Porritt J, Buchanan H, Hall M, Gilchrist F, Marshman Z. Assessing children's dental anxiety: a systematic review of current measures. Community Dent Oral Epidemiol 2013;41:130-42.

3. Armfield JM, Heaton LJ. Management of fear and anxiety in the dental clinic: a review. Aust Dent J 2013;58:390-407.

4. Oosterink FM, de Jongh $A$, Aartman $\mathrm{IH}$. What are people afraid of during dental treatment? Anxiety-provoking capacity of 67 stimuli characteristic of the dental setting. Eur J Oral Sci 2008;116:44-51.

5. Montedori A, Abraha J, Orso M, D’Errico PG, Pagano S, Lombardo G. Lasers for caries removal in deciduous and permanent teeth. Cochrane Database Syst Rev 2016;9:CD010229.

6. Cozean C, Arcoria CJ, Pelagalli J, Powell GL. Dentistry for the 21st Century? Erbium:YAG laser for teeth. J Am Dent Assoc 1997;128:1080-7.

7. Sarmadi R, Hedman E, Gabre P. Laser in caries treatment - patients' experiences and opinions. Int J Dent Hyg 2014;12:67-73.

8. Wong-Baker FACES Foundation [Internet]. Oklahoma City: WongBaker FACES $®$ Pain Rating Scale. Originally published in Whaley \& Wong's Nursing Care of Infants and Children [cited 2016]. (C) Elsevier Inc. Retrieved [02.03.2017] with permission from: http://www. WongBakerFACES.org

9. Klinberg G, Raadal M, Arnrup K. Dental fear and behavior management problems. Koch G, Poulsen S, editors. Pediatric dentistry: a clinical approach. 2nd edn. London: John Wiley \& Sons; 2009. p. 32-4.

10. Garra G, Singer AJ, Taira BR, Chauhan J, Cardoz H, Chisena E, Thode HC Jr. Validation of the Wong-Baker FACES Pain Rating Scale in pediatric emergency department patients. Acad Emerg Med 2010;17:50-4.

11. Bijur PE, Silver W, Gallagher EJ. Reliability of the visual analog scale for measurement of acute pain. Acad Emerg Med 2001;8:1153-7.

12. Güngör Ö, Yıldız E, Köylüoğlu Z, Hanımeli S, Küçükçetin İ, Öztürk O, et al. Çocuklardaki Dental Kaygının Psikometrik, Projektif ve Fizyolojik Testlerle Karşılaştırmalı Olarak Değerlendirilmesi. Turkiye Klinikleri J Pediatr Dent-Special Topics 2015;1:29-36.

13. Bulloch B, Tenenbein M. Validation of 2 Pain Scales for Use in the Pediatric Emergency Department. Pediatrics 2002;110:e33.

14. Bailey B, Trottier ED. Managing Pediatric Pain in the Emergency Department. Pediatr Drugs 2016;18:287-301.

15. Piaget J. The Early Growth of Logic in the Child. London: Routledge and Kegan Paul Ltd; 1964.

16. Shields BJ, Cohen DM, Harbeck-Weber C, Powers JD, Smith GA. Pediatric pain measurement using a visual analogue scale: a comparison of two teaching methods. Clin Pediatr 2003;42:227-34.

17. Chomyszyn-Gajewska M, Kwapinska H, Zarzecka J. Pain perception in children during caries removal with the Vector system: a pilot study.
Eur Arch Paediatr Dent 2006;7:38-41.

18. Topaloglu-Ak A, Eden E, Frencken JE. Perceived dental anxiety among schoolchildren treated through three caries removal approaches. J Appl Oral Sci 2007;15:235-40.

19. Anegundi RT, Patil SB, Tegginmani V, Shetty SD. A comparative microbiological study to assess caries excavation by conventional rotary method and a chemo-mechanical method. Contemp Clin Dent 2012;3:388-92.

20. Kumar K, Prasad G, Sandeep R, Reddy S, Divya D, Pratyusha K. Chemomechanical caries removal method versus mechanical caries removal methods in clinical and community-based setting: A comparative in vivo study. Eur J Dent 2016;10:386-91.

21. Dommisch H, Peus K, Kneist S, Krause F, Braun A, Hedderich J, et al. Fluorescence-controlled Er: YAG laser for caries removal in permanent teeth: a randomized clinical trial. Eur J Oral Sci 2008;116:170-6.

22. Eren F, Altinok B, Ertugral F, Tanboga I. The Effect of Erbium, Chromium:Yttrium-Scandium-Gallium-Garnet (Er,Cr:YSGG) Laser Therapy on Pain During Cavity Preparation in Paediatric Dental Patients: A Pilot Study. Oral Health Dent Manag 2013;12:80-4.

23. Hjertton PM, Bagesund M. Er:YAG Laser or High-Speed Bur for Cavity Preparation in Adolescents. Acta Odontol Scand 2013;71:610-5.

\section{Çocuk hastalarda Er:YAG lazer ile çürük uzaklaştııımasında ağrı algısının değerlendirilmesi: bölünmüş-ağız çalışması}

\section{ÖzeT}

AmAç: Çocuk hastaların dental tedavilerinde korku ve anksiyete önemli bir problem olarak karşımıza çıkmaktadır. Çürük temizleme aletlerinin kullanımı esnasında oluşan ağrı, çoğu çocuk ve yetişkinde dental korku ve anksiyeteyi tetikleyebilmektedir. Bu çalışmanın amacı; Er:YAG lazer ve geleneksel döner aletler kullanılarak çürük temizleme işlemi uygulanan çocuklardaki ağıı algılarını değerlendirmek ve karşılaştırmaktır.

GeREÇ VE YönTEM: Necmettin Erbakan Üniversitesi Diş Hekimliği Fakültesi Pedodonti Kliniğine başvuran 120 çocuk hastanın daimi molar dişlerindeki okluzal çürükler, Er:YAG lazer ve konvansiyonel çürük temizleme yöntemi olan yüksek ve düşük hızlı döner aletler kullanılarak uzaklaştırıldı. Tüm restoratif işlemler tek klinisyen tarafından gerçekleştirildi. Tedavi sonrası tüm çocuklardan WongBaker skalasındaki değer veya görsellerden bir tanesini seçmeleri istendi. Elde edilen verilerin değerlendirilmesinde Wilcoxon testi kullanıldı ( $\alpha=0.05)$.

BULGULAR: Çalışma grupları arasında istatistiksel fark gözlendi $(p<0.05)$. Er:YAG lazer grubunda 'canım acımıyor' seçeneği \%20.83 oranında seçilirken; konvansiyonel yöntem grubunda \%6.66 bulundu. 'Canım çok fazla acıyor' seçeneği hiçbir grupta seçilmedi.

Sonuç: Çalışmadan elde edilen sonuçlara göre; Er:YAG lazerlerin çürük temizleme amacıyla kullanılmasının geleneksel döner aletlere kıyasla daha az ağrıya sebep olduğu ve çocuk hastalar için daha konforlu ve kabul edilebilir bir yöntem olduğu düşünülebilir.

ANAHTAR Kelimeler: Ağrı algısı; diş çürükleri; Er-YAG lazerleri; pedodonti 